\title{
ХУЧТЭЙ ГАЗАР ХӨДЛӨЛТИЙН ЗАГВАРЧЛАЛ: ЭМЭЭЛТИЙН ХАГАРАЛ
}

\author{
М.Оюун-Эрдэнэ, Ч.Одонбаатар, Д.Ганзориг \\ ШУА-ийн Одон орон, геофизикийн судалгааны төв, Улаанбаатар-51/152, Монгол \\ Цахимиуудан: onii23@yahoo.com
}

\section{ОРШИЛ}

2013 оны байдлаар Монгол улсын нийслэл Улаанбаатар хотын хүн ам нь 1 сая 230 мянга болон өсч, өдрөөс өдөрт өргөжин тэлсээр байгаа юм. Улс орон хурдацтай хөгжихийн зэрэгцээ хотжилт, эдийн засгийн төвлөрөл эрчимтэй явагдаж байна. Энэ нь нийслэл хотын хөгжлийг хурдасган дэлхийн хөгжилтэй хотуудын зэрэглэлд ойртуулах сайн талтай боловч байгалийн элдэв гамшигт үзэгдэлд өртөх магадлалыг ихэсгэх хандлагатай байдаг.

1994-2000 онд Улаанбаатар хот орчимд газар хөдлөлтийг бүртгэх өндөр мэдрэмжтэй орчин үеийн тоон бичлэгтэй суурин станцыг байгуулснаар Улаанбаатар хотоос эргэн тойрон 100 км радиус бүхий орчинд болж буй газар хөдлөлтийн горим, ерөнхий төлөв байдлыг нарийвчлан судалж эХэлсэн. Харин 2005 оноос Улаанбаатар хот орчмын бүс нутагт газар хөдлөлтийн идэвхжилт өндөр ажиглагдаж байгаа бөгөөд идэвхжилтийн бүс нутагт хийгдсэн нарийвчилсан судалгааны үр дүнд Улаанбаатар хот орчимд хэд хэдэн хүчтэй газар хөдлөлтийн идэвхтэй голомт буюу хагарлын бүс байгааг тогтоосон. Эдгээр идэвхтэй хагарлуудаас газар хөдлөлтийн идэвхжилт сүүлийн жилүүдэд их явагдаж буй Эмээлтийн хагарлын бүс нутагт 2010 оноос эхлэн Франц, ОХУ-ын судлаачдын хамт геологи геофизикийн судалгаа явуулсан байдаг. судалгааны үр дүнгээс хархад Эмээлтийн хагарал нь Улаанбаатар хотын баруун хэсэгт хил залган Эмээлт өртөөнөөс баруун хойш 13 км орчим зайнд зүүн урагшаа $150^{\circ} \mathrm{N}$ азимутын чиглэлд оршиж байна гэж тогтоосон байна.. Мөн хагарлын газрын гадаргуу дээр болон сансрын зурагт илрүүлсэн хэсэг нь 5 км орчим бөгөөд 2005 оноос эхлэн ажиглагдаж буй газар хөдлөлтийн идэвхжилт, геофизикийн хэмжилтүүдийн үр дүнг үндэслэн хагарлын уртыг 35 км тогтоосон. Эмээлтийн хагарал дээр магнитуд нь 7.0 хүчтэй газар хөдлөлт болох боломжтой гэж үнэлсэн байна. [1], [2]

Газар хөдлөлтийн аюулыг багасгах нэг арга нь тухайн бүс нутагт үүсч болзошгүй газар хөдлөлтийн чичирхийллийг үнэлэх түүнд тэсвэртэй барилга байгууламж барих явдал юм. Орчин үед барилгын дизайн хийхийн тулд хүчтэй газар хөдлөлтийн загварчилсан бичлэгийг өргөн хэрэглэдэг болсон. Манай улсын хувьд одоогоор яг өөрийн оронд тооцоолон гаргасан бичлэг хэрэглэдэггүй байна. Бид энэХүҮ ажлаар Стохастик Грин функцийн аргыг ашиглан Эмээлтийн хагарал дээр хүчтэй газар хөдлөлт болоход голомтоос ирэх газар хөдлөлтийн синтетик сейсмограмыг Улаанбаатар хотын талбайн хувьд тооцон гаргах зорилго тавин ажилласан. Уг ажлыг гүйцэтгэхдээ бид хотын талбайг хадан хөрс гэж үзэн тооцооллыг хийсэн бөгөөд орчны геологийн нөхцөлийг тооцоонд оруулаагүй болно. Энэ чиглэлийн судалгааг 2011 онд хийсэн Одонбаатарын ажлаас харж болно. [3]

ЭнэхуҮ синтетик сейсмограмыг тооцон гаргаснаар Улаанбаатар хотын газар хөдлөлтийн аюулыг үнэлэх цаашид барилгын норм дүрэмд тусган оруулах чухал ач холбогдолтой юм. 


\section{СУДАЛГААНЫ АРГА ЗУЙ}

\section{Эмпирик Грин функцийн арга}

Газар хөдлөлтийн синтетик сейсмограмыг гарган авахын тулд бид газар хөдлөлтийн голомтын параметрүүд, голомтоос тухайн талбай хүртэлх долгионы тархах замын физик параметрүүд болон тухайн орчны параметр гэсэн 3 үндсэн процессыг мэдэх хэрэгтэй болдог. Хэрэв бидэнд тухайн голомтын бүсэд бичигдсэн сул газар хөдлөлтийн бичлэг байвал бид тухайн газар хөдлөлтийн бичлэгийн долгионы тархах зам болон бичлэг хийж буй орчны параметр нь тухайн бичлэгт орсон гэж үзэж болно. Энэ тохиолдолд газар хөдлөлтийн голомтыг сул газар хөдлөлтийн нийлбэр гэж үзэн газар хөдлөлтийн бичлэгийг тооцоолон гаргах аргыг Эмпирик Грин Функцийн (Empirical Green Function Method-EGFM) аргачлал гэж нэрлэдэг. [4]

Хугацааны эгшинд газар хөдлөлтийн Грин функц нь голомтын нөлөөлөл, тухайн долгионы замын нөлөөлөл, тухайн орчны нөлөөлөл болон багажийн нөлөөллийн харилцан үйлчлэлээр тодорхойлогддог. Хугацааны эгшинд газар хөдлөлтийн Грин функцийг $\mathrm{G}(\mathrm{t})$ гэж үзвэл:

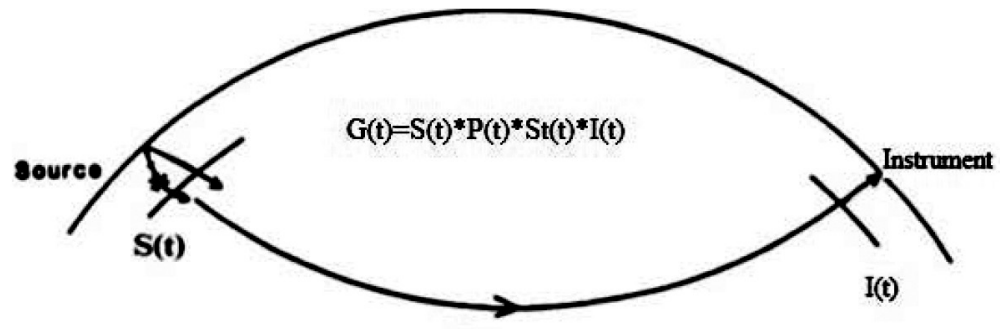

$P(t)$

Зураг 2 Хугаиаанаас хамаарах Грийн функи $G(t)$

$$
G(t)=S(t) \cdot P(t) \cdot S t(t) \cdot I(t)
$$

Энд: $\quad G(t)-$. Хугащааны эгшинд газар хөдлөлтийн Грин функи,

$S(t)$ - голомтын нөлөөлөл

$P(t)$ - тухайн долгионы замын нөлөөлөл

$S t(t)$ - тухайн орчны нөлөөлөл

$I(t)$ - багажийн нөлөөлөл

Грин функцийг давтамжийн тооллын системд задалж бичвэл газар хөдлөлтийн нь голомтын нөлөөлөл, тухайн долгионы замын нөлөөлөл, тухайн орчны нөлөөлөл

$$
\begin{aligned}
& G x(f)=S x(f) \cdot P x(f) \cdot S t x(f) \cdot I x(f) \\
& G c(f)=S c(f) \cdot P c(f) \cdot S t c(f) \cdot I c(f)
\end{aligned}
$$

болон багажийн нөлөөлөл зэрэг функцуудын үржвэр болдог. Хүчтэй болон сул газар хөдлөлтийн Грин функц нь

Энд: $\quad$ S- Газар хөдлөлтийн голомтын функи

$P$ - долгионы замаас хамаарах функи

St-талбайн нөлөөлөл (газар хөдлөлтийн долгион нь талбайн сэвсгэр 
хурдас, эсвэл ууланд тархахдаа тодорхой давтамжид өсгөлт болдог),
I - багажийн нөлөөлөл
х-хүчтэй газар хөдлөлт,
с- сул газар хөдлөлтийг төлөөлнө.

Нэг голомтод болсон хүчтэй болон сул хүчтэй газар хөдлөлтийн Грин функц нь газар хөдлөлтийн тархах зам, бүртгэгдэх орчин болон багаж ижил байна. Иймээс

дараах томъёогоор илэрхийлэгдэнэ.

$$
G x(f)=G c(f)
$$

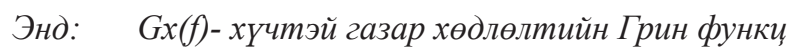

$G c(f)-$ Сул газар хөдлөлтийн Грин функи

Sx-ХYчтэй газар хөдлөлтийн голомтын функи,

Sc-Сул газар хөдлөлтийн голомтьлн функи,

Хэрэв бид сул газар хөдлөлтийн бичлэгийг гэж үзвэл хүчтэй газар хөдлөлтийн бичлэг - нь:

$$
G x(f)=G c(f) \frac{S x(f)}{S c(f)}
$$

Энд - Хүчтэй газар хөдлөлтийн бичлэг

филтерийн функи (засварын функи) сул болон хүчтэй хөдлөлийн хоорондын шилжилтийн хурдны хугащаанаас хамаарсан функцийн ялгаа

C- Сул болон хүчтэй газар хөдлөлтийн чөлөөлөгдсөн хүчдэлийн харьцаа

\section{Стохастик Грин функцийн арга}

Бидний судалж буй хагарлын хувьд судалгааны талбай болох Улаанбаатар хотын төв болон болон бусад дүүргүүдэд бичигдсэн сул $(\mathrm{M} 4.5-6)$ байх газар хөдлөлтийн бичлэг байхгүй тул шууд Эмпирик Грин функцийн аргыг шууд хэрэглэх боломжгүй юм. Ийм учраас бид сул газар хөдлөлтийн бичлэгийн оронд санамсаргүйгээр үүсгэсэн бичлэгийг хэрэглэдэг Stochastic Green Function Method (SGFM) гэдэг аргачлалыг хэрэглэн тооцооллыг хийлээ. ЭнэхYY SGFM арга нь Эмпирик Грин функцийн аргаас ялгаатай нь сул газар хөдлөлтийн бичлэгээ мөн урьд хийгдсэн судалгааны ажлуудад үндэслэн гаргаж авдаг юм.

\section{Мэдээлэл боловсруулалт, үр дүн}

2005 оноос эхлэн Улаанбаатар хот орчмын бүс нутагт тохиож буй газар хөдлөлтийн тоо огцом нэмэгдсэн бөгөөд хүнд мэдрэгдэм хүчтэй газар хөдлөлт хэд хэдэн удаа болсон. 2010 оноос эхлэн Франц, ОХУ-ын судлаачдын хамт энэхүу хагарал дээр геологи геофизикийн судалгаа явуулж Эмээлтийн хагарал нь Улаанбаатар хотын баруун хэсэгт хил залган Эмээлт өртөөнөөс баруун хойш 13 км орчим зайнд зүүн урагшаа $150^{\circ} \mathrm{N}$ азимутын чиглэлд Өлзийт хорооллыг дайрсан идэвхтэй хагарал оршиж байна гэж тогтоосон. Мөн хагарлын газрын гадаргуу дээр болон сансрын зурагт илрүүлсэн хэсэг нь 5 км орчим бөгөөд 2005 оноос эхлэн ажиглагдаж буй газар хөдлөлтийн идэвхжилт, геофизикийн хэмжилтүүдийн үр дүнг үндэслэн хагарлын уртыг 35 км тогтоосон. Эмээлтийн хагарал дээр магнитуд нь 7.0 хүчтэй газар хөдлөлт болох боломжтой гэж тодорхойлсон. Дээрх хагарлын параметрүүд болон 2013 оны 10 сарын 14-ний Ml=3.7 хүчтэй газар хөдлөлтийн голомтын механизм болох хагарлын азимут-328 $\quad$ ( $\varphi$-strike-өнцөг), хагарлын хэвтээ гадаргуутай үүсгэх налуу өнцөг-72 $(\sigma$-dip) хагарлын өнцөг шилжилт (slip)-ийг $67^{0}$ гэж тооцсон үр дүнгээр Стохастик Грин функцийн аргыг ашиглан синтетик сейсмограмыг гарган авсан.

Харин тооцооллыг хийхдээ 2005 
онд Японы газар хөдлөлтийн аюулыг детерминистик газрын зургийг зохиоход хэрэглэсэн Япон-жор хэмээх Ирикура нарын зохиосон алгоритмыг хэрэглэсэн болно. ЭнэХүу алгоритмд газар хөдлөлтийн голомтын параметрийг гадаад, нарийвчилсан болон ерөнхий гэсэн 3 хэсэгт хувааж үзсэн байна. Газар хөдлөлтийн бичлэг нь нарийвчилсан параметр буюу газар хөдлөлтийн голомтын асперити-гээс маш хүчтэй хамаардаг болохыг Ирикура, Сомербилл [5],[6] харж болно. Хагарлын параметрүүдийг геологи-геофизикийн судалгаагаар тогтоогдсон хагарлын урт, магнитуд, сул газар хөдлөлтийн хувьд тодорхойлсон голомтын механизм болон хагарлын параметрүүдийн эмпирик томъёонуудыг хэрэглэн тооцоолон гаргасан үр дүнг хүснэгт 1-т үзүүллээ.

ХУснэгт 1 Хагарльн параметрҮҮд

\begin{tabular}{|c|c|c|c|c|}
\hline \multicolumn{5}{|c|}{ Хагарлын ерөнхий параметр } \\
\hline Параметр & $\begin{array}{l}\text { Тэмдэг- } \\
\text { лэгээ }\end{array}$ & Ашигласан томъёо & $\begin{array}{c}\text { Гарсан үр } \\
\text { дүн }\end{array}$ & Нэгж \\
\hline Хагарлын урт & $\mathrm{L}$ & Судалгаанаас & $3.50 \mathrm{E}+04$ & $\mathbf{M}$ \\
\hline $\mathrm{M}(\mathrm{jma})$ & $\mathrm{M}(\mathrm{jma})$ & $(\log L+2.9) / 0.6$ & 7.4 & \\
\hline Сейсмик момент & Mo & $10^{\wedge}(1.17 \mathrm{M}(\mathrm{jma})+10.72)$ & $2.43 \mathrm{E}+19$ & $H^{*} M$ \\
\hline Момент магнитуд & $\mathrm{Mw}$ & $(\log \mathrm{Mo}-9.1) / 1.5$ & 6.9 & \\
\hline Хагарлын талбай & $\mathrm{S}$ & $\mathrm{L} * \mathrm{~W}$ & $5.69 \mathrm{E}+08$ & $\mathbf{M}^{\wedge} 2$ \\
\hline Хагарлын дундаж шилжилт & $\mathrm{D}$ & $\mathrm{Mo} / \mathrm{mS}$ & 1.29 & M \\
\hline Хагарлын өргөн & $\mathrm{W}$ & $\mathrm{W}=10^{\wedge}(0.667 * \log (\mathrm{L})+1.13)$ & $1.63 \mathrm{E}+04$ & $\mathbf{M}$ \\
\hline Эквивалент радиус & $\mathrm{R}$ & $\operatorname{sqrt}(\mathrm{S} / \mathrm{p})$ & $1.35 \mathrm{E}+04$ & $\mathbf{M}$ \\
\hline $\begin{array}{l}\text { Дундаж чөлөөлөгдсөн } \\
\text { хүчдэл }\end{array}$ & Ds & $(7 / 16)\left(\mathrm{Mo} / \mathrm{R}^{\wedge} 3\right)$ & $4.37 \mathrm{E}+06$ & Па \\
\hline Хурдатгалын түвшин & A & $2.46 \mathrm{E} 10 *(\mathrm{Mo} * 1 \mathrm{E} 7)^{\wedge}(1 / 3)$ & $1.54 \mathrm{E}+19$ & $\mathbf{H}^{*} \mathbf{M} / \mathbf{c e \kappa}^{2}$ \\
\hline \multicolumn{5}{|c|}{ Хагарлын нарийвчилсан параметр } \\
\hline Параметр & $\begin{array}{c}\text { Тэмдэг- } \\
\text { лэгээ }\end{array}$ & Ашигласан томъёо & $\begin{array}{c}\text { Гарсан үр } \\
\text { дүн }\end{array}$ & Нэгж \\
\hline $\begin{array}{l}\text { Асперитигийн эквивалент } \\
\text { радиус }\end{array}$ & $\mathrm{r}$ & $(7 \mathrm{p} / 4)^{*}\left(\mathrm{Mob}^{\wedge} 2 / \mathrm{AR}\right)$ & $6.31 \mathrm{E}+03$ & $\mathbf{M}$ \\
\hline Асперитигийн талбай & $\mathrm{Sa}$ & $\mathrm{pr}^{\wedge} 2$ & $1.25 \mathrm{E}+08$ & $\mathbf{M}^{2}$ \\
\hline Асперитигийн урт & $\mathrm{La}$ & $\mathrm{L}^{*} \operatorname{sqrt}(\mathrm{Sa} / \mathrm{S})$ & $1.64 \mathrm{E}+04$ & $\mathbf{M}$ \\
\hline Асперитигийн өргөн & Wa & $\mathrm{W}^{*} \operatorname{sqrt}(\mathrm{Sa} / \mathrm{S})$ & $7.62 \mathrm{E}+03$ & м \\
\hline $\begin{array}{l}\text { Асперитигийн дундаж } \\
\text { чөлөөлөгдсөн хүчдэл }\end{array}$ & Dsa & $(\mathrm{S} / \mathrm{Sa}) \mathrm{Ds}$ & $1.99 \mathrm{E}+07$ & Па \\
\hline $\begin{array}{l}\text { Асперитигийн шилжилтийн } \\
\text { дундаж }\end{array}$ & $\mathrm{Da}$ & $2 \mathrm{D}$ & 2.59 & $\mathbf{M}$ \\
\hline $\begin{array}{l}\text { Асперитигийн сейсмик } \\
\text { момент }\end{array}$ & Moa & $\mathrm{m} * \mathrm{Da} * \mathrm{Sa}$ & $1.07 \mathrm{E}+19$ & $\mathbf{H}^{*} \mathrm{M}$ \\
\hline Асперитигийн момент & Mwa & $(\log$ Moa-9.1)/1.5 & 6.6 & \\
\hline
\end{tabular}


Эмээлтийн хагарлын бүсэд $\mathrm{Ml}=7$ хүчтэй газар хөдлөлт болоход Улаанбаатар хотын талбайд ирж болзошгүй газар хөдлөлтийн синтетик сейсмограмыг Стохастик Грин функцийн аргыг ашиглан
Улаанбаатар хотын талбайг бүхэлд нь хадан хөрс гэж авч үзэн өргөргийн дагуу 16, уртрагийн дагуу 26 хувааж тор татан, нийт 416 цэгийн хувьд тооцон гаргалаа.

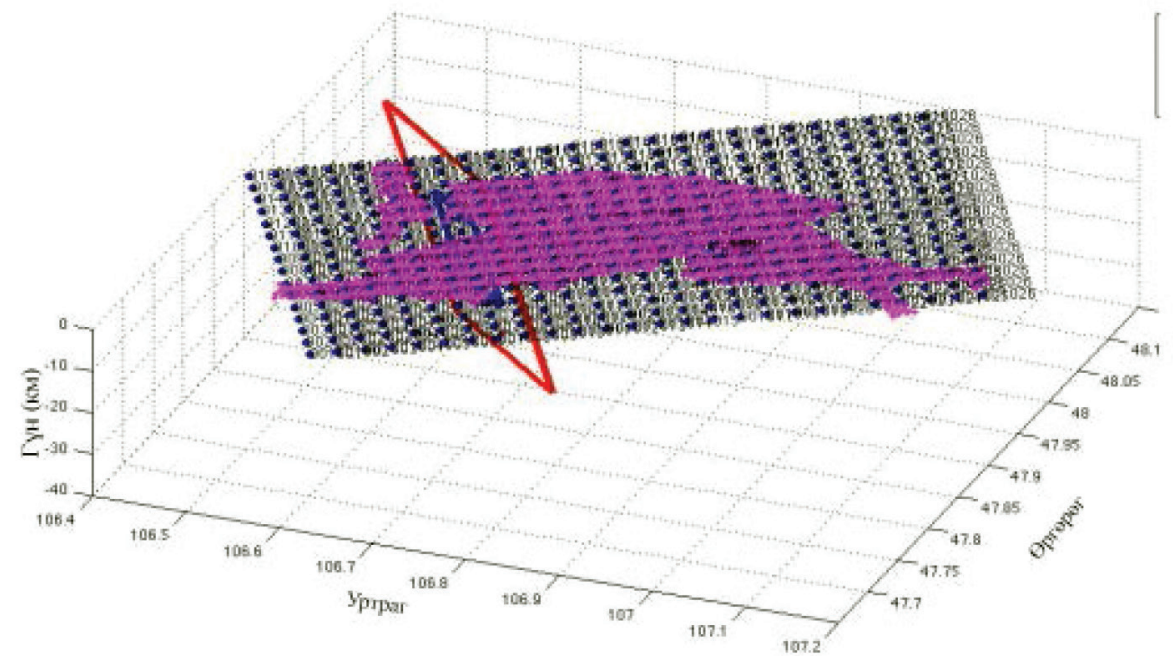

Зураг 3 Эмээлтийн хагарльн байрлал: саарал талбай - Улаанбаатар хотын талбайд бодолт хийсэн иэгүүд, тод гадна дөрвөлжин- Эмээлтийн хагарал, дотор дөрвөлжин -асперитигийн талбайг харуулав.

Дээрх тооцооллын үр дүнгээс харахад Эмээлт орчмын синтетик сейсмограмын хөрсний оргил хурдатгал нь 329 см/сек2, Биокомбинат орчимд хөрсний оргил хурдатгал нь 138 см/сек2, Хотын төв орчимд хөрсний оргил хурдатгал нь 124 см/сек2, Амгалан орчимд хөрсний оргил хурдатгал нь 94 см/сек2 байна. (Зураг 4- Зураг 7)

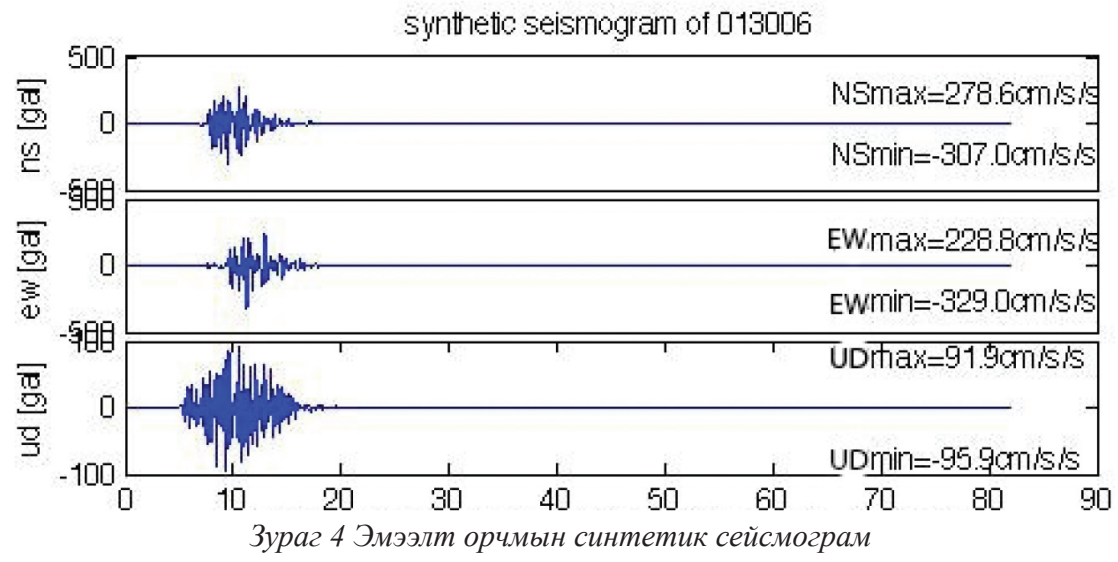



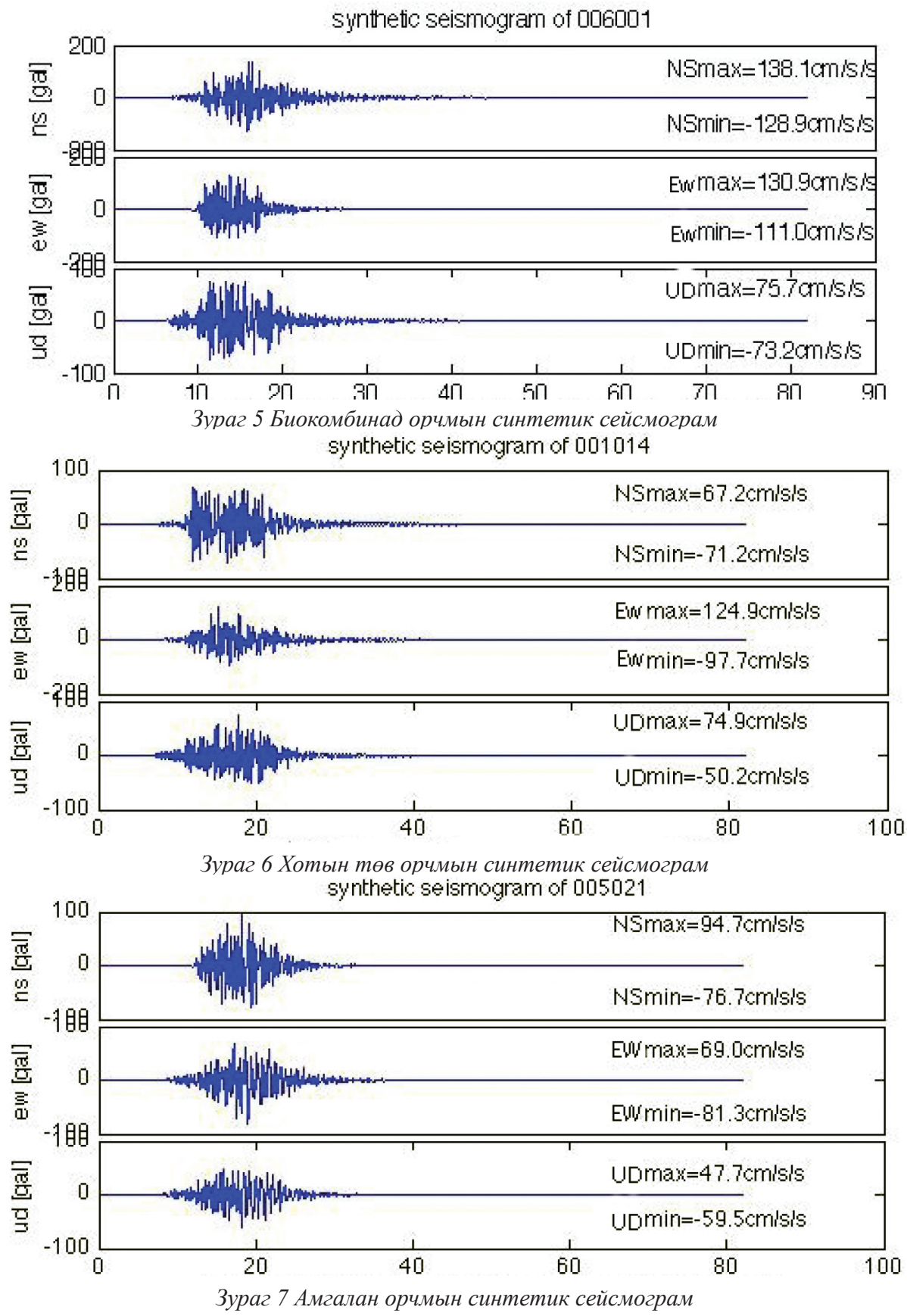

Тухайн цэг бүрт харгалзсан (өргөргийн дагуу 16, уртрагийн дагуу 26) хөрсний оргил хурдатгалыг тооцоолсон үр дүнгээс харахад хотын баруун хэсгээр 400 см/сек2, хотын төвийн хэсгээр 200 см/сек2 харин зүҮн хэсгээр 100 см/сек2 байлаа. (Зураг 8) 


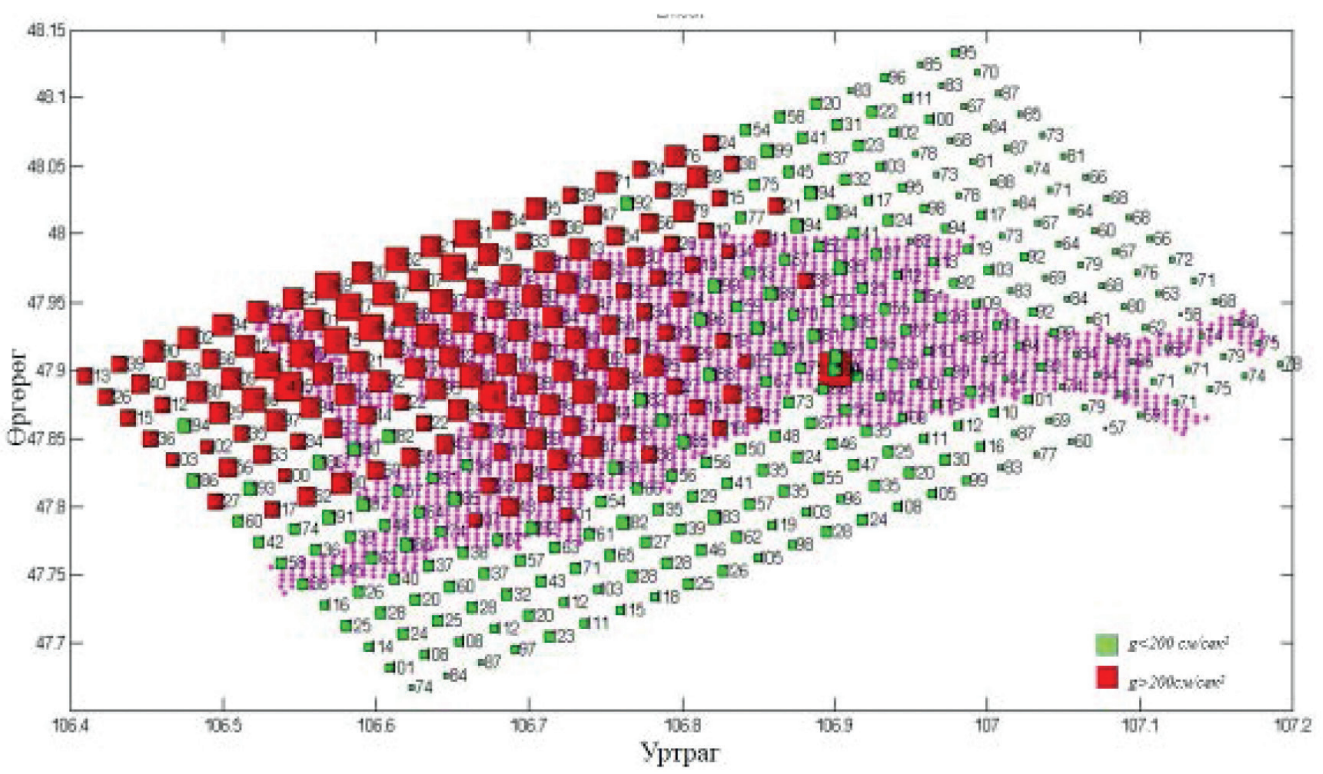

Зураг 8 Улаанбаатар хотын талбайд ирэх их хөрсний оргил хурдатгальн үр дүн

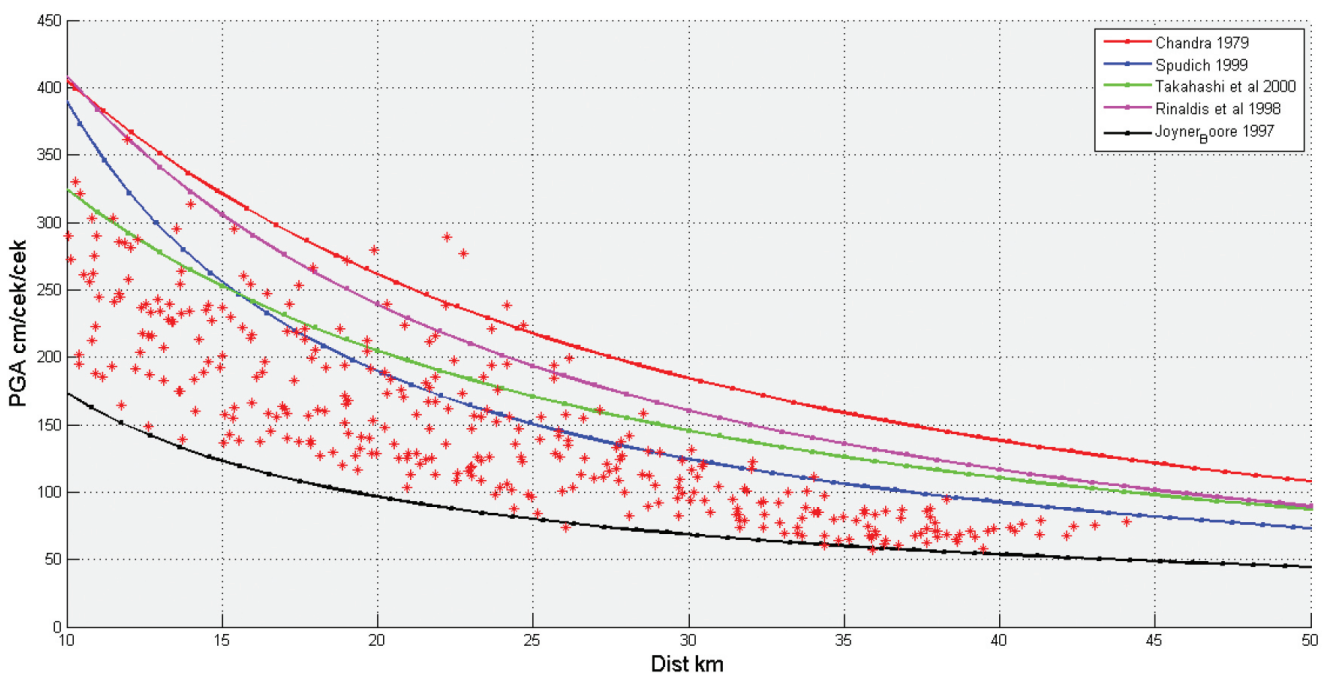

Зураг 9 Синтетик сейсмограммаас гарган авсан хөрсний оргил хурдатгалыг

Эмпирик замхаралтын хуулиудтай харьиуулсан харьцаа (од-бидний тооцооллын утга)

Эмээлтийн хагарал дээр $\mathrm{Mw}=7$ хүчтэй газар болоход Улаанбаатар хотын талбайд өргөргийн дагуу 16 уртрагийн дагуу 26 хувааж тор татан, нийт 416 цэгийн хувьд хөрсний оргил хурдатгал тооцолсон үр дүнг олон улсад ашиглагдаж буй Эмпирик замхралтын хуулиудтай харьцуулсан. Үүнд: Chandra 1979, Spudich 1999, Takahashi et al
2000, Rinalds et al 1998, Joyner Boore 1997. [9]

Эдгээр эмпирик хуулиуд нь Монголтой төстэй эх газар болсон газар хөдлөлтийн ажиглалтын үр дүнгээс гарган авсан хөрсний оргил хурдатгалын зай, магнитуд , болон газар хөдлөлтийн төрлөөс хамааруулан гарган долгионы 
авсан замхралтын тодорхойлох хуулиуд юм. Тиймээс орчны геологийн онцлог газар хөдлөлтийн комплекс байдал зэргээс хамааран бидний тооцоотой яг таарах боломжгүй боловч харьцуулсан үр дүнгээс хархад ойролцоо утга өгч байлаа.

\section{ДҮГНЭЛТ}

Хүчтэй газар хөдлөлтийн голомтоос тухайн талбайд нөлөөлөх газар хөдлөлтийн долгионыг загварчлан гаргах Стохастик Грин функцийн аргыг ашиглан газар хөдлөлтийн идэвхжилт өндөр ажиглагдаж байгаа Эмээлтийн хагарлын синтетик сейсмограмыг тооцон гаргалаа.

Эмээлтийн хагарал дээр $\mathrm{Mw}=7$ хүчтэй газар хөдлөлт болоход Улаанбаатар хотын талбайг өргөргийн дагуу 16 цэг, уртрагийн дагуу 26 цэг тус бүрт хувааж тор татан, нийт 416 цэгийн хувьд синтетик сейсмограмыг гарган авч хөрсний оргил хурдатгалыг тооцоолсон. Тооцооллын үр дүнгээс харахад хөрсний оргил хурдатгал хамгийн ихдээ хотын баруун хэсгээр 400 см/сек ${ }^{2}$, хотын төвийн хэсгээр 200 см/сек ${ }^{2}$ харин зүүн хэсгээр 100 см/сек² байлаа.

\begin{tabular}{lcr} 
Энэхүу & судалгаанд & \multicolumn{2}{c}{ синтетик } \\
& тооцоолол & нь
\end{tabular} сейсмограмын тооцоолол нь нэг
параметрүүдийн цаашид оролтын параметрүүдийг өөрчлөх, сайжруулах замаар илүҮ бодитой олон төрлийн бичлэгийг тооцоолон гаргах нь зайлшгүй шаардлагатай юм.

Синтетик сейсмограмыг тооцоолон гаргаж үр дүнг олон улсад ашиглагдаж буй Эмпирик замхралтын хуулиудтай харьцуулсан.

Газар хөдлөлтийн аюулыг үнэлэхэд чухал параметр болох синтетик сейсмограмыг тооцон гаргаснаараа энэХүY ажил нь чухал ач холбогдолтой юм.

\section{Ашигласан бүтээлийн жагсаалт}

1. “Улаанбаатар хот орчмын хүчтэй газар хөдлөлтийн идэвхэилтийн бүсэд нарийвчилсан судалгаа хийх” ажльн тайлан 2013 он, хуудас 111-130

2. Монгол орны газар хөдлөлтийн идэвхжсил, аюулын үнэлгээний ба дэлхийн гүний тогтиылн судалгаа 2011-2013 тайлан, хуудас 95-98

3. Ch.Odonbaatar "Characterization of Site Effects in the Ulaanbaatar Basin" thesis at Strasbourg university, France, 2011

4. Kajiro Irikura (Aichi Institude of Technology and Kyoto University), Hiroe Miyake (Earthquake Research Institute, University of Tokyo) "Lecture Note on Strong Motion Seismology"

5. $\quad$ Aki K (1967) Scaling law seismic spectrum, J Geophys Res., 72, 1217-1231

6. Somerville, P., Irikura.,R Graves, D. Wald, N. Abrahamson,. Y Iwasaki, T. Kagawa, N. Smith and A. Kowada (1999) Characterizing crustal earthquake slip models for the prediction of strong ground motion, Seismol.Res.Lett., 70, 59-80

7. Irikura, K Recipe predicting strong ground motions from future large earthquake, Animals of disaster Prevention Researcher Institude 47A 25-45(In Japanese with English abstract)

8. Eshelby J.D. (1957), The determination of the elastic field of an ellipsoidal inclusion, and related problems Proc, Roy Soc., A241, 376-396

9. J. Dougles "Engineering seismology and Earthquake Engineering" ESEE Report No.01-1 January 2001 


\begin{abstract}
New seismic network was deployed around Ulaanbaatar city since 1994. These seismic stations give us a chance to observe and locate even small events around Ulaanbaatar. Last 10 years, 8000 earthquake registered around Ulaanbaatar. Most of the activity is related to the Emeelt fault. The resent scientist work was conclude that length of fault is approximately $35 \mathrm{~km}$ and maximum credible magnitude $M w=7$.

In this work we attempt to calculate strong ground motion generated by Emeelt active fault to the Ulaanbaatar area using stochastic Green function method. Fault parameters are determined using small event that occurred in Emeelt fault area. The calculation was made using Japan- recipe algorithm that developed by Irikura. As result we successfully obtain time history for 416 sites in Ulaanbaatar area. The result shows the Ground motion PGA in the west part of Ulaanbaatar has approximately $400 \mathrm{sm} / \mathrm{s}^{\wedge} 2$ and east part $100 \mathrm{sm} / \mathrm{s}^{\wedge} 2$.

The estimated strong ground motion time histories will be one of the important parameter to estimate seismic hazard assessment for Ulaanbaatar city.
\end{abstract}

